\title{
Research into the Contribution Rate of Technological Progress to the Industrial Economic Growth of Xinjiang
}

\author{
Lu Wen ${ }^{1, \mathrm{a}}$, Zhang Rong ${ }^{2, \mathrm{~b}}$, and Bai Xiao ${ }^{3, \mathrm{c}, *}$ \\ 1,2,3Faculty of Transportation and Management,Xinjiang Vocational and Technical College of Communications,Urumqi,Xinjiang,China
}

\begin{abstract}
Since the Silk Road Economic Belt initiative was put forward in 2013,the industrial structure of Xinjiang has become increasingly rationalized,and Xinjiang’s economic development has entered a stage of rapid development.Based on the Solow residual value method,this paper uses the gray correlation model to estimate the elastic coefficient of capital and labor input and calculates the contribution rate of technological progress in 25 industrial sectors in Xinjiang.The research results show that more than $50 \%$ of the industrial sector in Xinjiang contributes more than 50\% to technological progress,and Xinjiang's economy has entered a period of intensive rapid development.
\end{abstract}

\section{Introduction}

With the introduction of the Silk Road Economic Belt initiative in 2013,Xinjiang has become the core of the new Silk Road Economic Belt due to its superior geographical location.Xinjiang has become the growth pole of economic development in western China,and industry is the core of regional economic development.The healthy development of the industrial sector is very important to the regional economy.To ensure the healthy,sustained and rapid development of the industry,the core is the level of science and technology.Therefore,measuring the contribution rate of science and technology to economic growth in the industrial sector is an important indicator for measuring economic development and an important factor for measuring the sustainable development of the industry.Existing research on the contribution rate of technological progress to the promotion of regional economic development is relatively abundant: Liu Z.(2021) measured the contribution rate of technological progress to economic growth in Hunan Province[1];Wang L.,et al.(2020) measured the contribution rate of food technology progress in Hunan Province under the new development concept[2];Yang X.et al.(2020) studied the contribution rate of supplyside factors to China's economic growth[3]; $\mathrm{Lv}$ X.M.,Zhang Yong l.(2019) studied the impact of technological progress on the adjustment of China's industrial structure based on the perspective of industry and regional differences [4];Zheng S.L.,Zhang M.C.(2019) studied the contribution rate of technological progress to China's economic growth from 1990 to 2017 [5];Guo C.,et al.(2019) calculated based on the consideration of capital deepening and the contribution rate of total factor productivity Improved labor productivity in China's manufacturing industry[6];Cao
M.X.and Gao S.(2018) conducted research on China's agricultural total factor productivity based on the agricultural panel of Jiangsu Province [7];Cheng M.L.(2018) measured the contribution rate of China's agricultural technological progress [8].A large number of studies on the contribution rate of technological progress show that technological progress in the process of social development has a certain effect on the study of regional economic development.Due to the different development levels of technological innovation at different stages,the degree of promotion of the economy is also different.Although the existing research results are relatively rich,there is a lack of literature on the contribution rate of technological progress to the economic growth of Xinjiang among the existing research results.Xinjiang is located in the core area of the Silk Road Economic Belt.Since the proposal of the New Silk Road Economic Belt was put forward,has the level of technological innovation played a significant role in promoting the economy of Xinjiang? Is it necessary for the regional government to give preferential support for technological research?This paper mainly studies this issue.

\section{SELECTION OF ECONOMIC MODEL}

In economic research,the origin of the quantitative analysis of the effects of various elements of economic growth is the C-D function model.In 1928,the famous CD function model proposed by the University of Chicago economics professor Douglas and the mathematician Cobb,for the first time introduced the methods of economics and modeling into production for analysis.However,the C-D function can only describe the relationship between input and output at a constant technological level,so it cannot be used to analyze the role of technological progress in economic growth [9].In

c*Corresponding author: 41468463@qq.com 
1942,Dutch economist Ding B.G.added a time variable to the C-D function, and for the first time raised the issue of total factor productivity (that is,technological progress in a broad sense),making it possible to measure technological progress.In 1957,the American economist Solow incorporated technological progress into the production function based on the research of Douglas and Ding B.G., and for the first time quantitatively separated the growth role of technological progress in the economy [10].Most existing scholars use this improved function model to measure the contribution rate of technological progress in the economy.This paper also uses this relatively mature method to measure the contribution rate of Xinjiang's technological progress from 2014 to 2019 and briefly analyzes the level of technological progress in Xinjiang's economic growth.

The Solow residual method is widely used because of its simple calculation and easy data collection.It is called the "residual value method" because it equates the contribution rate of technological progress to economic growth as the sum of all other factors remaining after deducting the contribution rate of labor and capital investment.Therefore,technological progress here refers to technological progress in a broad sense.The calculation formula is:

$$
A=y-\alpha k-\beta l
$$

Here,A refers to the speed of technical progress,y is the output growth rate, $\mathrm{k}$ is the growth speed of capital investment, $l$ is the growth speed of labor investment, $\alpha$ is the elastic coefficient of capital investment, and $\beta$ is the elastic coefficient of labor investment.

The traditional elastic coefficient is based on the production function under certain premises and assumptions and is obtained by the least square method.A small sample size will have a greater impact on the regression results. This paper only measures the contribution rate of technological progress in the industrial sector of Xinjiang since the Silk Road Economic Belt initiative was put forward in 2013,and the data sample size is small.The gray correlation analysis method uses the similarity of the geometric shape of the data sequence curve to judge the correlation size,which is more suitable for the case of a small sample size.Therefore,this paper adopts grey relational analysis to calculate the elasticity coefficient of capital and labor.

\section{CALCULATION OF THE CONTRIBUTION RATE OF XINJIANG'S TECHNOLOGICAL PROGRESS}

In order to analyze the promotion effect of the technological progress of Xinjiang's industrial sector on industrial development in detail,this paper divides the Xinjiang's industrial sector into 25 and conducts the calculation of the contribution rate of technological progress.Table 1,Table 2,Table 3 show the specific data..

Table 1 The Output Value of Various Industrial Sectors in Xinjiang Unit: 100 million yuan

\begin{tabular}{|c|c|c|c|c|c|c|}
\hline Industrial Sectors & 2014 & 2015 & 2016 & 2017 & 2018 & 2019 \\
\hline Coal mining products industry & 269.88 & 231.74 & 201.16 & 264.18 & 305.33 & 383.48 \\
\hline Oil and gas mining industry & 140.04 & 856.26 & 659.66 & 899.84 & 1141.39 & 1160.31 \\
\hline Metal mining products & 213.90 & 152.05 & 144.27 & 197.88 & 201.79 & 207.87 \\
\hline $\begin{array}{l}\text { Non-metallic minerals and other mining and processing } \\
\text { products }\end{array}$ & 22.08 & 18.21 & 13.27 & 16.04 & 15.07 & 19.68 \\
\hline Food and tobacco industry & 766.99 & 883.80 & 923.02 & 936.20 & 872.62 & 924.29 \\
\hline Textile industry & 144.42 & 141.48 & 229.07 & 390.86 & 446.49 & 428.47 \\
\hline $\begin{array}{l}\text { Textile,clothing,shoes,hats,leather and its products } \\
\text { industry }\end{array}$ & 14.97 & 28.99 & 47.57 & 29.30 & 24.14 & 37.11 \\
\hline Woodworking products and furniture industry & 13.82 & 14.26 & 18.60 & 20.35 & 16.47 & 18.49 \\
\hline $\begin{array}{l}\text { Papermaking printing and cultural,educational and } \\
\text { sporting goods }\end{array}$ & 40.20 & 49.80 & 60.58 & 55.34 & 25.88 & 30.94 \\
\hline $\begin{array}{l}\text { Petroleum,coking products and nuclear fuel processed } \\
\text { products }\end{array}$ & 1768.73 & 1163.30 & 1063.40 & 1402.49 & 1645.52 & 1531.57 \\
\hline Chemical product & 943.68 & 867.97 & 952.76 & 1260.08 & 1276.29 & 1218.33 \\
\hline Non-metallic mineral products & 428.92 & 390.05 & 424.08 & 519.25 & 498.55 & 663.54 \\
\hline Metal smelting and rolled products & 1367.19 & 1115.61 & 1226.11 & 1751.02 & 1695.17 & 1692.41 \\
\hline Metal products & 108.95 & 77.09 & 71.69 & 88.17 & 60.06 & 78.05 \\
\hline General equipment & 21.33 & 19.90 & 13.02 & 13.27 & 5.08 & 5.52 \\
\hline Professional setting & 48.82 & 40.88 & 34.61 & 33.35 & 34.05 & 54.10 \\
\hline Transportation equipment & 43.96 & 18.97 & 20.12 & 30.53 & 30.96 & 36.63 \\
\hline Electrical machinery and equipment & 377.84 & 498.66 & 480.78 & 424.43 & 353.09 & 417.06 \\
\hline $\begin{array}{l}\text { Communication equipment,computers and other } \\
\text { electronic equipment }\end{array}$ & 1.71 & 1.92 & 2.47 & 4.33 & 29.58 & 8.38 \\
\hline Instrumentation & 1.18 & 1.17 & 0.70 & 0.52 & 0.23 & 0.23 \\
\hline
\end{tabular}




\begin{tabular}{|l|l|l|l|l|l|l|}
\hline Other manufactured products and scrap & 5.22 & 3.34 & 4.28 & 6.96 & 21.26 & 32.42 \\
\hline $\begin{array}{l}\text { Repair service of metal products,machinery and } \\
\text { equipment }\end{array}$ & 2.13 & 2.67 & 1.93 & 2.79 & 3.20 & 6.96 \\
\hline Electricity and heat production and supply & 996.32 & 897.36 & 918.47 & 1241.33 & 1300.71 & 1442.47 \\
\hline Gas production and supply & 100.87 & 91.95 & 95.08 & 105.18 & 123.22 & 150.90 \\
\hline Water production and supply & 10.20 & 17.26 & 16.18 & 23.37 & 26.44 & 35.88 \\
\hline
\end{tabular}

Data Sources: Xinjiang Statistical Yearbook 2015 2020,calculated based on the deflated values using 2014 as the base period.

Table 2 The amount of investment in fixed assets in various sectors of industry in Xinjiang Unit: 100 million yuan

\begin{tabular}{|c|c|c|c|c|c|c|}
\hline Industrial Sectors & 2014 & 2015 & 2016 & 2017 & 2018 & 2019 \\
\hline Coal mining products industry & 437.81 & 410.31 & 457.09 & 496.75 & 438.13 & 511.45 \\
\hline Oil and gas mining industry & 4240.07 & 4857.80 & 5129.66 & 5086.97 & 1231.18 & 5348.02 \\
\hline Metal mining products & 216.32 & 234.93 & 243.17 & 263.40 & 268.10 & 274.79 \\
\hline $\begin{array}{l}\begin{array}{l}\text { Non-metallic minerals and other mining and } \\
\text { processing products }\end{array} \\
\end{array}$ & 18.57 & 14.96 & 11.98 & 10.76 & 10.21 & 13.14 \\
\hline Food and tobacco industry & 515.35 & 501.00 & 614.89 & 523.56 & 552.10 & 539.06 \\
\hline Textile industry & 158.43 & 140.01 & 221.02 & 295.12 & 337.61 & 360.96 \\
\hline $\begin{array}{l}\text { Textile,clothing,shoes,hats,leather and its products } \\
\text { industry }\end{array}$ & 2.98 & 27.06 & 44.01 & 6.84 & 7.09 & 6.54 \\
\hline Woodworking products and furniture industry & 12.83 & 8.72 & 12.65 & 11.05 & 7.60 & 7.63 \\
\hline $\begin{array}{l}\text { Papermaking printing and cultural,educational and } \\
\text { sporting goods }\end{array}$ & 23.42 & 22.82 & 27.44 & 27.47 & 25.47 & 23.96 \\
\hline $\begin{array}{l}\begin{array}{l}\text { Petroleum,coking products and nuclear fuel } \\
\text { processed products }\end{array} \\
\end{array}$ & 962.50 & 1058.85 & 1019.93 & 1077.71 & 1244.66 & 1289.44 \\
\hline Chemical product & 1281.49 & 1581.80 & 1941.98 & 1823.49 & 1718.39 & 1815.60 \\
\hline Non-metallic mineral products & 488.57 & 547.54 & 599.01 & 620.77 & 610.63 & 828.17 \\
\hline Metal smelting and rolled products & 1239.89 & 1398.83 & 1379.28 & 1455.17 & 1428.85 & 1440.81 \\
\hline Metal products & 31.54 & 34.85 & 31.92 & 33.69 & 37.89 & 39.26 \\
\hline General equipment & 6.43 & 10.33 & 8.58 & 8.04 & 5.23 & 3.35 \\
\hline Professional setting & 24.34 & 29.56 & 32.63 & 30.28 & 31.26 & 34.19 \\
\hline Transportation equipment & 22.33 & 24.33 & 24.33 & 23.88 & 23.10 & 22.30 \\
\hline Electrical machinery and equipment & 64.94 & 72.68 & 76.95 & 79.72 & 89.17 & 60.90 \\
\hline $\begin{array}{l}\text { Communication equipment,computers and other } \\
\text { electronic equipment }\end{array}$ & 1.96 & 3.87 & 5.01 & 4.27 & 53.54 & 8.44 \\
\hline Instrumentation & 0.09 & 0.10 & 0.07 & 0.07 & 0.17 & 0.13 \\
\hline Other manufactured products and scrap & 10.25 & 10.56 & 11.63 & 7.66 & 9.17 & 19.23 \\
\hline $\begin{array}{l}\text { Repair service of metal products,machinery and } \\
\text { equipment }\end{array}$ & 0.51 & 0.60 & 0.60 & 0.59 & 0.52 & 0.82 \\
\hline Electricity and heat production and supply & 2562.93 & 3190.24 & 4039.39 & 4517.83 & 4727.23 & 5158.05 \\
\hline Gas production and supply & 180.42 & 174.35 & 189.53 & 188.14 & 336.98 & 340.13 \\
\hline Water production and supply & 64.64 & 92.83 & 100.59 & 134.85 & 189.54 & 218.20 \\
\hline
\end{tabular}

Data Sources: Xinjiang Statistical Yearbook 2015 2020,calculated based on the deflated values using 2014 as the base period.

Table 3 Employed population in various sectors of industry in Xinjiang Unit: Person

\begin{tabular}{|l|l|l|l|l|l|l|}
\hline Industrial Sectors & 2014 & 2015 & 2016 & 2017 & 2018 & 2019 \\
\hline Coal mining products industry & 62525 & 56244 & 45910 & 42403 & 38508 & 41427 \\
\hline Oil and gas mining industry & 73107 & 70740 & 66445 & 63739 & 60504 & 57419 \\
\hline Metal mining products ming and & 3823 & 3124 & 2775 & 2737 & 2026 & 2196 \\
\hline $\begin{array}{l}\text { Non-metallic minerals and other mining } \\
\text { processing products }\end{array}$ & 87322 & 80290 & 82114 & 74045 & 70873 & 68796 \\
\hline Food and tobacco industry & 31758 & 32501 & 49670 & 63843 & 68119 & 68014 \\
\hline $\begin{array}{l}\text { Textile industry } \\
\text { Textile,clothing,shoes,hats,leather and its products } \\
\text { industry }\end{array}$ & 2435 & 8961 & 13094 & 11685 & 12113 & 27358 \\
\hline
\end{tabular}




\begin{tabular}{|l|l|l|l|l|l|l|}
\hline Woodworking products and furniture industry & 5425 & 2261 & 2197 & 2144 & 1765 & 1789 \\
\hline $\begin{array}{l}\text { Papermaking printing and cultural,educational and } \\
\text { sporting goods }\end{array}$ & 8058 & 6842 & 6575 & 5157 & 4571 & 5597 \\
\hline $\begin{array}{l}\text { Petroleum,coking products and nuclear fuel } \\
\text { processed products }\end{array}$ & 48406 & 45969 & 41610 & 40276 & 42672 & 44192 \\
\hline Chemical product & 106756 & 102025 & 100753 & 100317 & 97456 & 96951 \\
\hline Non-metallic mineral products & 62694 & 58810 & 52268 & 51604 & 48627 & 55897 \\
\hline Metal smelting and rolled products & 91020 & 83370 & 75816 & 71243 & 66323 & 64088 \\
\hline Metal products & 9857 & 10697 & 8193 & 7544 & 6152 & 6978 \\
\hline General equipment & 3013 & 2847 & 1746 & 1440 & 1167 & 850 \\
\hline Professional setting & 4500 & 4911 & 3933 & 3787 & 4156 & 4490 \\
\hline Transportation equipment & 2735 & 2638 & 2121 & 1876 & 1943 & 2298 \\
\hline Electrical machinery and equipment & 17268 & 14796 & 17313 & 13021 & 11609 & 11699 \\
\hline $\begin{array}{l}\text { Communication equipment,computers and other } \\
\text { electronic equipment }\end{array}$ & 530 & 753 & 2503 & 2278 & 2530 & 1475 \\
\hline Instrumentation & 109 & 178 & 190 & 211 & 114 & 72 \\
\hline Other manufactured products and scrap & 236 & 268 & 674 & 679 & 708 & 1222 \\
\hline $\begin{array}{l}\text { Repair service of metal products,machinery and } \\
\text { equipment }\end{array}$ & 732 & 1163 & 812 & 1104 & 1086 & 1797 \\
\hline Electricity and heat production and supply & 71461 & 63059 & 75701 & 77092 & 72244 & 76583 \\
\hline Gas production and supply & 9084 & 8492 & 8750 & 8189 & 10159 & 10663 \\
\hline Water production and supply & 2910 & 3586 & 4058 & 4828 & 5195 & 6984 \\
\hline
\end{tabular}

Data Sources: Xinjiang Statistical Yearbook 2015 2020.

Table 4 Contribution Rate of Technological Progress in Various Sectors of Xinjiang's Industry Unit: \%

\begin{tabular}{|l|l|}
\hline Industrial Sectors & $\begin{array}{l}\text { Contribution } \\
\text { rate }\end{array}$ \\
\hline Coal mining products industry & 119.14 \\
\hline Oil and gas mining industry & 76.83 \\
\hline Metal mining products & 380.78 \\
\hline $\begin{array}{l}\text { Non-metallic minerals and other mining and } \\
\text { processing products }\end{array}$ & 4948.54 \\
\hline Food and tobacco industry & 122.32 \\
\hline Textile industry & 32.18 \\
\hline $\begin{array}{l}\text { Textile,clothing,shoes,hats,leather and its } \\
\text { products industry }\end{array}$ & 9.91 \\
\hline $\begin{array}{l}\text { Woodworking products and furniture } \\
\text { industry }\end{array}$ & 245.09 \\
\hline $\begin{array}{l}\text { Papermaking and } \\
\text { cultural,educational and sporting goods }\end{array}$ & 490.81 \\
\hline $\begin{array}{l}\text { Petroleum,coking products and nuclear fuel } \\
\text { processed products }\end{array}$ & 1447.67 \\
\hline Chemical product & 47.1 \\
\hline Non-metallic mineral products & 46.18 \\
\hline Metal smelting and rolled products & 121.59 \\
\hline Metal products & 52.67 \\
\hline General equipment & 12.5 \\
\hline Professional setting & 32.1 \\
\hline Transportation equipment & 136.11 \\
\hline Electrical machinery and equipment & 173.19 \\
\hline $\begin{array}{l}\text { Communication equipment,computers and } \\
\text { other electronic equipment }\end{array}$ & 78.92 \\
\hline Instrumentation & 144.92 \\
\hline Other manufactured products and scrap & 43.83 \\
\hline
\end{tabular}

\begin{tabular}{|l|l|}
\hline $\begin{array}{l}\text { Repair service of metal products,machinery } \\
\text { and equipment }\end{array}$ & 44.71 \\
\hline Electricity and heat production and supply & 14.37 \\
\hline Gas production and supply & 17.94 \\
\hline Water production and supply & 21.29 \\
\hline
\end{tabular}

According to the data of Table 1 3,the gray correlation method is used to calculate the $\alpha$ and $\beta$ coefficients of various sectors of the industry,and the C$\mathrm{D}$ model is further used for measurement.The results are as follows (Table 4).

According to Liu S.F.(1998) [11] on the evaluation of industrial development,industries with a contribution rate of technological progress greater than $50 \%$ are relatively well developed industries in the region;industries with a contribution rate of technological progress between $30 \%$ and $50 \%$ It is an industry with a relatively good development status in the region;and an industry with a contribution rate of less than $30 \%$ of technological progress is a general industry developed in the region.According to the calculation results of table 4,the contribution rate of technological progress in 14 industrial sectors has exceeded 50\%,including nonmetallic minerals and other mining and processing products,petroleum,coking products and nuclear fuel processing products,metal mining products,wood processed products and furniture industry,papermaking and printing,cultural,educational and sporting goods industry,electrical machinery and equipment,instrumentation,food and tobacco industry,transportation equipment,metal smelting and rolling products,coal mining and processing products,oil and gas mining industry,communication equipment,computers and other electronic equipment,metal products; the contribution rate of 
technological progress in the 6 industrial sectors is between $30 \%$ and 50\%,including textiles,chemical products,non-metallic mineral products,special equipment,other manufactured products and waste products,metal products,machinery and equipment repairs industry;only 5 industrial sectors have contributed less than $30 \%$ of technological progress,including the production and supply of textiles,clothing,shoes,hats,leather and feather products,general equipment,electricity,and heat,water production and supply,and gas production and supply.It can be seen from the calculation results that over $50 \%$ of the industrial sectors have a technological progress rate greater than $50 \%$.This shows that the Xinjiang region has entered a stage of intensive economic growth,and technological innovation has greatly promoted the development of the industrial sector in Xinjiang.

\section{CONCLUSIONS AND ANALYSIS}

Based on the Solow residual value method,the grey relational model is used to determine the capital elasticity coefficient and the labor elasticity coefficient,this paper further measures the contribution rate of technological progress in various sectors of industry in Xinjiang from 2014 to 2019 since the Silk Road Economic Belt initiative was put forward.The research results show that the overall development of the industrial sector in Xinjiang is very good.More than 50\% of the industrial sectors have a contribution rate of more than $50 \%$ of technological progress, and only a few industrial sectors have a relatively low contribution rate of technological progress. This shows that the industrial economy of Xinjiang has entered a stage of intensive economic growth.In the future,it is necessary to further increase technological innovation and technology research and development to further promote the leapforward and healthy development of Xinjiang's industrial sector.

\section{References}

1. Liu Zhi,Niu Jun.The calculation and analysis of the contribution rate of technological progress to economic growth: Based on the data of Hunan Province from 1983 to 2018 [J].Journal of Jiaozuo University,2021,35(01): 59-63.

2. Wang Li,Min Rui,Ma Yuqing.Measurement and analysis of the contribution rate of food technology progress in Hunan Province under the new development concept[J].Journal of Central South University of Forestry and Technology (Social Science Edition),2020,14(06): 89-95.

3. Yang Xinrong,Tang Jingting,Yang Yongjun,Huang Daqian.An Empirical Study on the Contribution Rate of Supply-side Factors to China's Economic Growth[J].Statistics and Decision,2020,36(20): 119123.

4. Lv Xiaomeng,Zhang Yongliang.Research on the Impact of Technological Progress on my country's
Industrial Structure Adjustment: An Empirical Analysis Based on Industrial and Regional Differences[J].Price Theory and Practice,2019(07): 157-160.

5. Zheng Shilin,Zhang Meichen.Estimated contribution rate of scientific and technological progress to China's economic growth: 1990 to 2017 [J].World Economy,2019,42(10): 73-97.

6. Guo Chunna,Chen Chunchun,Peng Xuhui.Recalculation of Labor Productivity in China's Manufacturing Industry: Based on the Consideration of Capital Deepening and Total Factor Productivity Contribution[J].Price Theory and Practice,2018(07): 151-154.

7. Cao Mingxia,Gao Shan.Research on my country's Agricultural Total Factor Productivity: Based on the Analysis of Agricultural Panel Data in Jiangsu Province[J].Price Theory and Practice,2018(09): 151-154.

8. Cheng Maolin,Han Yun.The calculation of the contribution rate of agricultural technology progress[J].Statistics and Decision,2018,34(14):3335.

9. Charles W Cobb,Paul H Douglas.A Theory of Production[J].American Economic Review, 1928,(18):61-94

10. Solow R M.Technical Change and the Aggregate Production Function[J].Review of Economics an Statistics, 1957,8(39):312-320

11. Liu Sifeng,Li Bingjun,Yang Ling,Zhu Yongda.Evaluation Indexes and Mathematical Models of Regional Leading Industries[J].China Management Science,1998(02):9-14. 